\title{
The Effect of Purified Lipopolysaccharide on the Bactericidal Reaction of Human Serum Complement
}

\author{
By R. J. ALLEN AND G. K. SCOTT* \\ Department of Biochemistry, University of Auckland, Private Bag, \\ Auckland, New Zealand
}

(Received 8 June 1979; revised 19 September 1979)

\begin{abstract}
Escherichia coli ML308 225 was killed and lysed by human serum. Bacterial sensitivity to serum was maximal for organisms in the early-exponential phase of batch culture and declined as growth proceeded. Bacterial killing was dependent upon the complete complement sequence and the subsequent action of serum lysozyme caused bacteriolysis. Purified lipopolysaccharide from this organism bound to serum-sensitive bacteria and inhibited the bactericidal reaction.
\end{abstract}

\section{INTRODUCTION}

Lipopolysaccharide (LPS) is an important component of the Gram-negative bacterial outer membrane and the relationship between the chemical structure of LPS and bacterial sensitivity to serum is well known. The so-called smooth strains of Escherichia coli and Salmonella typhimurium are relatively resistant to serum, whereas rough strains, in which the LPS lacks peripheral carbohydrate residues, are more susceptible to the lethal action of complement (Rowley, 1954; Lüderitz et al., 1971). A quantitative relationship between LPS levels and serum sensitivity has also been reported by Wardlaw (1963), although his experiments were performed with two distinct strains of $E$. coli, in which LPS levels may not have been the only factors influencing serum sensitivity. Similar results with $S$. typhimurium strains were reported by Archer \& Rowley (1969).

The ability to protect bacteria from complement action is a property of LPS as part of the bacterial outer membrane complex. Isolated LPS has been shown to activate the classical and alternative pathways of the complement system (Morrison \& Kline, 1977). These two effects do not appear to be directly related, although it is possible that excessive complement activation by high concentrations of LPS in the bacterial outer membrane could contribute to bacterial resistance to complement. We have examined the effect of isolated LPS from E. coli ML308 225 on the serum bactericidal reaction of this organism.

\section{METHODS}

Growth of bacteria. Escherichia coli ML308 225 was a gift from Dr W. A. Hamilton of the Department of Biochemistry, University of Aberdeen. It was maintained on nutrient agar slopes. Liquid cultures were grown at $37{ }^{\circ} \mathrm{C}$ in minimal salts medium containing $0.5 \%(\mathrm{w} / \mathrm{v})$ glucose. Growth was monitored by reading absorbance at $650 \mathrm{~nm}$ in $1 \mathrm{~cm}$ cuvettes in an MSE Spectroplus spectrophotometer. Cultures were harvested by centrifugation.

Sera. Human sera were obtained fresh from healthy volunteers and also from outdated blood supplied by the Auckland Regional Blood Transfusion Centre. Bactericidally active sera were pooled and stored frozen at $-80^{\circ} \mathrm{C}$. This material was used without further treatment as a source of human serum complement. Antibacterial antiserum was prepared by multiple subcutaneous injection of rabbits with heat-killed cultures of 
E. coli ML308 225, followed by bleeding from the marginal ear vein. The serum was tested for its ability to agglutinate bacterial suspensions.

Antisera to human serum complement component C9 and to human serum lysozyme were purchased from Hoechst, New Zealand, and were heated to $56^{\circ} \mathrm{C}$ for $30 \mathrm{~min}$. They were used to deplete human serum of $\mathrm{C} 9$ and lysozyme, respectively. Human serum $(1 \mathrm{ml})$ was treated with $0.1 \mathrm{ml}$ of the antiserum at $4{ }^{\circ} \mathrm{C}$ for $2 \mathrm{~h}$ and then centrifuged. This treatment was repeated once. Control samples were incubated with two portions of heated rabbit serum. Serum depleted of C9 did not form a precipitin line with this antiserum in double diffusion analysis. Serum depleted of lysozyme retained less than $5 \%$ of the lysozyme activity of normal serum.

Assay of bacterial killing and lysis. Freshly harvested bacteria were resuspended in the assay buffer, which was $30 \mathrm{~mm}$-Tris $/ \mathrm{HCl}$, pH $7 \cdot 5$, containing $0.15 \mathrm{~mm}-\mathrm{CaCl}_{2}$ and $0.02 \mathrm{~mm}-\mathrm{MgSO}_{4}$. Assay mixtures contained up to $0.2 \mathrm{ml}$ serum and up to $0.4 \mathrm{ml}$ LPS solution. The total volume was $1.0 \mathrm{ml}$ and the bacterial suspension was adjusted to give approximately $2.5 \times 10^{8}$ bacteria in each assay mixture. Assay mixtures were incubated at $37^{\circ} \mathrm{C}$ for up to $60 \mathrm{~min}$. Viable counts were made using serially diluted samples spread on nutrient agar plates followed by overnight incubation at $37^{\circ} \mathrm{C}$. Results are expressed as the percentage of bacteria surviving after a given time.

Similar bacterial suspensions and serum concentrations were used to measure bacteriolysis. Spectrophotometric determination of absorbance at $650 \mathrm{~nm}$ was used as a measure of turbidity. Results are expressed as the percentage of the initial turbidity at a given time.

Complement fixation by bacteria. A suspension of washed bacteria was centrifuged and then resuspended in a small volume of human serum. This suspension was quickly recentrifuged and $5 \mu \mathrm{l}$ samples of the supernatant serum were applied to radial immunodiffusion plates specific for human $\mathrm{C} 4$ and human factor $\mathrm{B}$ (Hoechst, New Zealand). This procedure compensated for dilution of the serum with residual buffer from the bacterial pellet. The bacteria were resuspended in the serum and incubated at $37^{\circ} \mathrm{C}$ for specified times. Following centrifugation, $5 \mu \mathrm{l}$ samples were taken for radial immunodiffusion. The plates were incubated at room temperature for $48 \mathrm{~h}$ and the diameters of the precipitin discs were measured. The percentage of each component remaining was given by: $100 \times(\text { diameter of precipitin disc of sample after reaction })^{2} /$ (diameter of precipitin disc of sample before reaction) ${ }^{2}$.

These experiments were also performed with bacterial suspensions which had been incubated for $30 \mathrm{~min}$ with LPS solutions and then centrifuged and washed.

Purification of lipopolysaccharide. Freshly harvested or cold acetone-dried bacteria were extracted with $45 \%$ (v/v) aqueous phenol at $65^{\circ} \mathrm{C}$ as described by Westphal \& Jann (1965). The resulting aqueous extract was dialysed overnight against distilled water at $4{ }^{\circ} \mathrm{C}$ and freeze-dried. The freeze-dried extract was redissolved in $2.0 \mathrm{ml}$ assay buffer and fractionated on a column of Sepharose $4 \mathrm{~B}(85 \times 1.5 \mathrm{~cm}$, equilibrated with assay buffer). The flow rate was $10 \mathrm{ml} \mathrm{h}^{-1}$ and fractions of $2.5 \mathrm{ml}$ were collected. The carbohydrate content of fractions was measured using the method of Devor (1950) and the absorbance at $260 \mathrm{~nm}$ and $280 \mathrm{~nm}$ of the fractions was also determined. Fractions 16 to 35 were routinely pooled and samples from this pool were used as a crude LPS preparation.

Further purification was commenced by adding pancreatic deoxyribonuclease (1 mg; Sigma DN25) and pancreatic ribonuclease ( $1 \mathrm{mg}$; Sigma Type $1-\mathrm{A}$ ) to the pool and incubating for $4 \mathrm{~h}$ at $37^{\circ} \mathrm{C}$, followed by a further similar incubation with Streptomyces griseus protease $(1 \mathrm{mg}$; Sigma Type IV). The solution was then dialysed for $16 \mathrm{~h}$ against distilled water at $4{ }^{\circ} \mathrm{C}$ and freeze-dried. The solid material was redissolved in $2 \mathrm{ml}$ assay buffer and chromatography on Sepharose 4B was repeated. A pool was made as before. The carbohydrate content of the pool was measured, using glucose as a standard. The protein content was measured by Lowry's method, using bovine serum albumin as a standard. The nucleic acid content was measured by comparing the absorbance at $260 \mathrm{~nm}$ with standard DNA and RNA solutions.

Lipid content of lipopolysaccharide. Samples $(2.0 \mathrm{ml})$ of the pool of purified LPS were each mixed with an equal volume of $2 \%(\mathrm{v} / \mathrm{v})$ acetic acid and incubated at $100{ }^{\circ} \mathrm{C}$ for $4 \mathrm{~h}$. The resulting precipitates were washed twice with distilled water and dried in vacuo. They were then used to prepare fatty acid methyl esters as described by Ackman (1969). These samples were subjected to gas-liquid chromatography using the Pye Unicam 104 apparatus. The column was $1.2 \mathrm{~m} \times 6 \mathrm{~mm}$ and was packed with Chromosorb G containing $2.5 \%(\mathrm{v} / \mathrm{w})$ diethyleneglycolsuccinate. The carrier gas flow was $40 \mathrm{ml} \mathrm{N}_{2} \mathrm{~min}^{-1}$ and the temperature programme was $135^{\circ} \mathrm{C}$ for $1 \mathrm{~min}$ followed by heating at $7^{\circ} \mathrm{C} \mathrm{min}-1$ to $205^{\circ} \mathrm{C}$. Fatty acid methyl esters were detected in the effluent using a flame ionization detector. Standards were purchased from Sigma. The methyl ester of $\beta$-hydroxymyristic acid was identified by its relative retention time (Marr \& Ingraham, 1962).

Radioactive lipopolysaccharide. Tritiated LPS was prepared as described above. Bacteria were grown to the late-exponential phase $\left(A_{650}=0.9\right)$ in a minimal salts medium $(101)$ containing $\mathrm{D}-\left[1-{ }^{3} \mathrm{H}\right] \mathrm{glucose}$ [sp.act. $3 \mu \mathrm{Ci} \mathrm{g}^{-1}\left(110 \mathrm{kBq} \mathrm{g}^{-1}\right)$; Amersham]. The purified LPS had a specific activity of $0 \cdot 14 \mu \mathrm{Ci} \mathrm{g}^{-1}\left(5 \cdot 2 \mathrm{kBq}^{-1}\right)$.

The binding of tritiated LPS to bacteria was measured in reaction mixtures similar to those used in the bactericidal assays. Following incubation of bacteria with LPS, the reaction mixtures were centrifuged and samples $(0.1 \mathrm{ml})$ from the supernantats were dried on $21 \mathrm{~mm}$ diam. glass fibre discs (Whatman GF/C). The 


\section{Table 1. Fixation of complement components by bacteria}

Radial immunodiffusion was used to measure the concentrations of components $\mathrm{C} 4$ and factor $\mathrm{B}$ in serum before and after reaction with bacteria.

$\begin{array}{cccc}\begin{array}{c}\text { Expt } \\ \text { no. }\end{array} & \text { Experimental conditions } & \begin{array}{c}\text { Percentage of } \\ \text { C4 remaining }\end{array} & \begin{array}{c}\text { Percentage of } \\ \text { Factor B remaining }\end{array} \\ 1 & \begin{array}{c}1.5 \times 10^{10} \text { bacteria in } 0.5 \mathrm{ml} \text { serum; } 37^{\circ} \mathrm{C} ; 1 \mathrm{~h} \\ 2\end{array} & 100 & 70 \\ 3 & 0 \cdot 7 \times 10^{10} \text { bacteria in } 0.2 \mathrm{ml} \text { serum; } 37^{\circ} \mathrm{C} ; 3 \mathrm{~h} \\ \text { rabbit antibacterial serum; } 37^{\circ} \mathrm{C} ; 3 \mathrm{~h} & 94 & 50 \\ 4 & \begin{array}{l}\text { As expt 3, except that cells were reacted } \\ \text { with } 0.5 \mathrm{mg} \text { LPS for 30 min prior to reaction } \\ \text { with serum }\end{array} & 49 & 50 \\ & 46 & 45\end{array}$

discs were put into standard scintillation vials and $1 \mathrm{ml}$ toluene containing $0 \cdot 27 \%(\mathrm{w} / \mathrm{v}) 2$,5-diphenyloxazole was added to each. Radioactivity was measured for 10 min intervals in a Packard Tri-Carb liquid scintillation spectrometer. Background radioactivity was measured with samples of assay buffer dried on to glass fibre discs. The efficiency of radioactive counting, measured using samples of a tritium standard (Packard) dried on to glass fibre discs, was $32 \%$.

Extraction of bound lipopolysaccharide. A culture $(100 \mathrm{ml})$ in the early-exponential phase of growth was harvested and the cells were resuspended in $10 \mathrm{ml}$ assay buffer. Tritiated LPS $(1 \mathrm{ml})$ was added. Following incubation for 10 or $60 \mathrm{~min}$, the bacteria were washed with assay buffer, resuspended in $10 \mathrm{ml} 5 \mathrm{~mm}$-EDTA, pH 7.2, for 5 min and centrifuged, and finally resuspended in $10 \mathrm{ml}$ assay buffer and extracted with $10 \mathrm{ml}$ $90 \%(\mathrm{w} / \mathrm{v})$ phenol at $65{ }^{\circ} \mathrm{C}$. Samples of each supernatant were taken for radioactive counting. This experiment was also done with a sample $(25 \mathrm{ml})$ taken from the late-exponential phase of a batch culture; this sample was incubated for $60 \mathrm{~min}$ with $1 \mathrm{ml}$ tritiated LPS, and then washed and extracted as described above.

\section{RESULTS}

\section{Bacterial killing and lysis by serum}

A series of bactericidal experiments was performed at different stages of the growth of a single batch culture. The initial rate of bacterial killing was measured in each case and was converted to a percentage of the initial rate of killing at $A_{650}=0 \cdot 15$. It was found that bacterial killing was very slow for organisms from the initial lag before growth commenced. The rate of killing rose rapidly to a maximum in bacteria from the early-exponential growth phase and then declined more slowly as growth proceeded. Bacteria from the stationary phase were completely resistant to the action of serum complement under the assay conditions used. For the remainder of the bactericidal experiments reported here, bacteria were harvested at $A_{650}=0 \cdot 15$.

Typically the bacteria were rapidly killed and lysis followed rather more slowly. When human serum was depleted of lysozyme by immunoprecipitation, lysis was almost entirely abolished, with no detectable effect on bacterial killing. Depletion of complement component $\mathrm{C} 9$ completely inhibited both killing and lysis by serum; in fact, there was a slight increase in the viable count of bacteria indicating that the organisms began to utilize the serum for growth. Confirmation of the involvement of the complement system in the killing and lysis of $E$. coli ML308 225 came from experiments with radial immunodiffusion. Table 1 shows the results of three experiments (expts 1 to 3 ) using a single batch of serum. In the absence of added antiserum, prolonged incubation of bacteria and serum led to significant fixation of factor B $(50 \%)$ but only a small quantity of component $\mathrm{C} 4$ was fixed $(6 \%)$. Addition of antibacterial serum stimulated $\mathrm{C} 4$ fixation but had no effect on factor B fixation. It may be concluded that $E$. coli ML308 225 activated the alternative complement pathway when reacted with human serum and that the addition of antibacterial serum was not required. Analysis of other serum samples using this technique has shown that, in some cases, C4 fixation occurred without added antibacterial serum (L. T. Guan, personal 
Table 2. Effect of lipopolysaccharide on bacterial viability

Additions were made to bactericidal assay mixtures and viable counts were determined as described in Methods.

$\begin{array}{ccc}\begin{array}{c}\text { Addition to stan- } \\ \text { dard bactericidal assay }\end{array} & \begin{array}{c}\text { LPS added } \\ (\mu \mathrm{g})\end{array} & \begin{array}{c}\text { Bacterial viability } \\ \text { after 60 min } \\ (\%)\end{array} \\ \text { None } & 0 & 6 \\ \text { Crude LPS } & 20 & 1 \\ & 100 & <1 \\ \text { Purified LPS } & 400 & 32 \\ & 22 & 4 \\ \text { Purified LPS* } & 110 & 34 \\ & 440 & 111 \\ & 22 & 9 \\ & 110 & 28\end{array}$

* Bacteria were reacted with purified LPS and then washed prior to use in the standard bacter icidal assay.

communication). This observation may imply the occurrence of natural antibodies in those samples. Factor B fixation was always observed.

\section{Purification and characterization of bacterial lipopolysaccharide}

The first gel filtration of the phenol extract showed that there was considerable contamination of the LPS with nucleic acid and protein of high molecular weight. This contamination was almost entirely eliminated by treatment with nucleases and protease; the nucleic acid and protein levels were less than 1 and $0.5 \%$, respectively, of the carbohydrate content of the final pool. Identical samples of acetone-dried bacteria $(905 \mathrm{mg})$ from early-exponential $\left(A_{650}=0.15\right)$ and late-exponential $\left(A_{650}=0.9\right)$ stages of batch cultures yielded 32.0 and $21.2 \mathrm{mg}$ LPS, respectively. The total fatty acids corresponded to about 10 to $11 \%$ of the carbohydrate. $\beta$-Hydroxymyristic acid was the major fatty acid present, although lauric and myristic acids were also present in significant amounts and traces of palmitic acid appeared in the LPS prepared from bacteria from the late-exponential phase of batch cultures.

\section{Effect of lipopolysaccharide on the bactericidal reaction}

Table 2 summarizes the results of experiments in which samples of a crude LPS extract and of a purified LPS preparation were added to bactericidal assay mixtures. The higher concentrations of both LPS preparations inhibited bacterial killing but there was a slight stimulation of the bactericidal reaction by low concentrations of the crude LPS extract. This effect was not observed with highly purified LPS preparations. LPS also retained the ability to inhibit the bactericidal reaction if the bacteria were treated with the preparations and then washed prior to adding human serum (Table 2). These results were obtained using LPS extracted from the bacteria in the late-exponential phase of batch culture. Similar results (not shown) were obtained with similar quantities of LPS from bacteria in the earlyexponential phase of growth.

The extent of binding of tritiated LPS to bacteria was measured (Fig. 1). A series of bactericidal assays were set up, using $0.2 \mathrm{ml}$ serum in each and different volumes of the tritiated LPS solution. A similar series of mixtures, without the added serum, was set up simultaneously. At the end of the bactericidal experiment, the mixtures lacking serum were centrifuged. The radioactivity remaining in the supernatants was used to calculate the amounts of LPS bound to the cells. Only a relatively small proportion of the added LPS became bound to the cells. The cells in a standard assay mixture were apparently saturated with LPS when about $13 \mu \mathrm{g}$ had been bound and the addition of higher concentrations of 


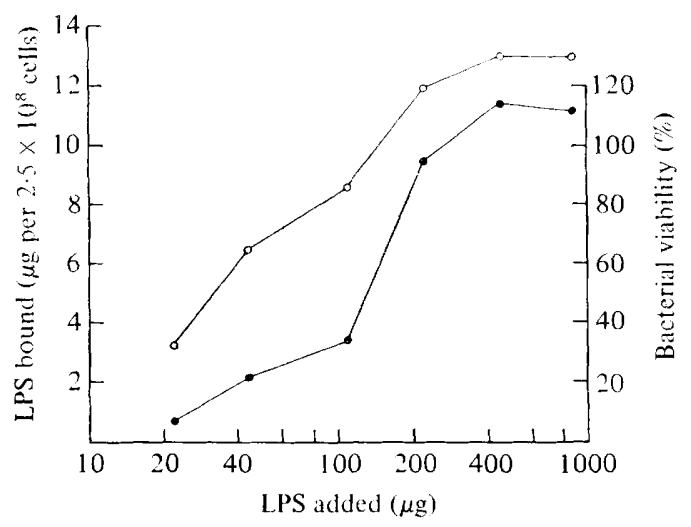

Fig. 1. Inhibition of bacterial killing by LPS bound to bacteria. Two series of bacterial suspensions were incubated with different amounts of tritiated LPS. One series was used for bactericidal assays and the other was used to measure the amount of radioactivity bound to the bacteria. The amount of cell-bound LPS was calculated from the specific activity of the tritiated LPS. LPS bound to bacteria, $\bigcirc$; bacterial viability,

Table 3. Extraction of bound lipopolysaccharide from bacteria

$\begin{array}{cccccc}\begin{array}{c}\text { Total LPS } \\ \text { added to } \\ \text { bacteria } \\ (\mu \mathrm{g})\end{array} & \begin{array}{c}\text { Reaction } \\ \text { time } \\ (\mathrm{min})\end{array} & \begin{array}{c}\text { LPS recovered } \\ \text { after reaction } \\ \text { with bacteria } \\ (\mu \mathrm{g})\end{array} & \begin{array}{c}\text { LPS recovered } \\ \text { by washing } \\ \text { bacteria } \\ (\mu \mathrm{g})\end{array} & \begin{array}{c}\text { LPS recovered } \\ \text { by EDTA } \\ \text { extraction } \\ (\mu \mathrm{g})\end{array} & \begin{array}{c}\text { LPS recovered } \\ \text { by phenol } \\ \text { extraction } \\ (\mu \mathrm{g})\end{array} \\ \begin{array}{c}440 *(100 \%) \\ 440 *(100 \%)\end{array} & 10 & 308(70 \%) & 80(18 \%) & 26(6 \%) & 0.5(0 \cdot 1 \%) \\ 440 \dagger(100 \%) & 60 & 321(73 \%) & 53(12 \%) & 36(8 \%) & 17(4 \%) \\ * & 364(83 \%) & 68(15 \%) & 1(0 \cdot 2 \%) & -\end{array}$

LPS did not result in any further binding. The extent of LPS binding correlated with the inhibition of the bactericidal reaction; saturation with LPS led to complete inhibition of the bactericidal reaction.

Table 1 (expt 4) indicates that pre-treatment of bacteria with inhibitory concentrations of LPS did not markedly affect the fixation of complement components by the bacteria. Agglutination of bacteria by specific antiserum was not affected by a similar pre-treatment with LPS.

\section{Extraction of bound tritiated lipopolysaccharide}

Bacteria from the early-exponential phase of batch culture were treated with tritiated LPS for 10 or $60 \mathrm{~min}$ and were then washed, extracted with EDTA and finally extracted with phenol at $65^{\circ} \mathrm{C}$. The amounts of LPS rem oved from the organisms at each stage were calculated (Table 3). LPS not removed by washing with assay buffer was considered to be cell-bound. Following a 10 min incubation, $6 \%$ of the total LPS was cell-bound, most of which could be re-extracted with EDTA. Following a $60 \mathrm{~min}$ incubation, $12 \%$ of the total LPS was cell-bound, of which $8 \%$ could be re-extracted with EDTA and $4 \%$ could only be removed by extraction with phenol. Bacteria from the late-exponential phase of batch culture were treated with tritiated LPS for $60 \mathrm{~min}$; washing with assay buffer removed almost all of the LPS.

\section{DISCUSSION}

We have shown that Escherichia coli ML308 225 from the exponential growth phase of batch cultures was readily killed by human serum complement. Complement activation followed the classical or alternative pathways, or both, but component $C 9$ was essential for 
bacterial killing, in contrast to haemolysis, for which $\mathrm{C} 9$ was not an absolute requirement (Stolfi, 1968). Other workers have also reported that C9 was necessary for bacterial killing (Feingold et al., 1968). Subsequent lysis of the killed bacteria apparently depended upon serum lysozyme. This is in agreement with observations on other strains of $E$. coli (Davis et al., 1966; Feingold et al., 1968; Wilson \& Glynn, 1975) although it has also been reported that lysis of $E$. coli can occur following treatment with lysozyme-depleted serum (Glynn \& Milne, 1967). We have not observed reduced bactericidal ability in lysozyme-depleted serum.

The purification of the LPS of E. coli ML308 225 was more complex than has been reported (Westphal \& Jann, 1965). Two gel filtration steps were essential; attempts to degrade enzymically the nucleic acid and protein in the phenol extract led to almost total loss of LPS. Presumably the first gel filtration removed a low molecular weight hydrolase which was responsible for this degradation. The purified LPS was comparable with those described by other workers (Lüderitz et al., 1971).

LPS represents $3.5 \%$ of the dry weight of bacteria harvested in the early-exponential growth phase, but only $2 \cdot 3 \%$ of the organisms harvested at the end of the period of exponential growth. A similar effect has been noted with the outer membrane proteins of this strain (Allen \& Scott, 1979) and may relate to the release of outer membrane fragments from E. coli reported by Rothfield \& Pearlman-Kothencz (1969). A direct link between LPS and outer membrane protein concentrations in $S$. typhimurium has also been reported (Ames et al., 1974).

Purified LPS inhibited the bactericidal action of serum on E. coli ML308 225, apparently through binding of the LPS to the bacteria. The amounts of LPS required for this effect were very large and it was considered possible that LPS was merely serving as an alternative substrate for complement action and that, following the washing of cells treated with LPS, residual LPS had the same effect. However, the extent of inhibition of the bactericidal reaction paralleled the binding of tritiated LPS to bacteria. This observation showed that the inhibition was not due to complement activation by residual LPS in the fluid phase. The complement fixation experiments were carried out with a large excess of bacteria relative to serum. Under these conditions, complement fixation was not affected by bound LPS. If bound LPS had inhibited complement activation, complement fixation would have been reduced.

The nature of the interaction between added LPS and bacteria has been examined. After a 10 min exposure to added LPS, most of the LPS could be removed by washing the bacteria. Almost all of the LPS still bound to the bacteria was removed by a 5 min exposure to 5 mM-EDTA. A similar treatment has been reported to remove about $50 \%$ of the intrinsic LPS from $E$. coli (Leive, 1965). Under the conditions used to compare LPS binding and bactericidal inhibition, half of the bound LPS could be removed by washing with assay buffer. The remainder of the tritiated LPS was only removed by EDTA and phenol treatment and was thus as firmly bound as the intrinsic LPS of the cells.

An early-exponential phase 101 culture contained about $10^{13}$ cells and yielded about $32 \mathrm{mg}$ pure LPS. Assuming that the yield of the phenol extractions and purification approached $100 \%$, there was thus about $8 \mu \mathrm{g}$ LPS in the $2.5 \times 10^{8}$ cells in a bactericidal assay mixture. The binding of about $13 \mu \mathrm{g}$ added LPS was sufficient to totally protect these cells from complement action. Of this $13 \mu \mathrm{g}, 6.5 \mu \mathrm{g}$ was firmly bound. This calculation may be related to the observation that, in $E$. coli, LPS covers about half of the cell surface (Di Rienzo et al., 1978). We suggest that the protective effect of LPS is due to its binding to the cell surface in such a way as to 'fill the gaps' left by the intrinsic LPS. These results may also be related to the observation that bacterial endotoxin (LPS) can bind to eukaryotic cell surfaces (Keogh et al., 1948). A similar phenomenon has been reported by Glynn \& Howard (1970), who showed that $E$. coli $\mathrm{K}$ antigens bound to erythrocytes and inhibited antibody binding and haemolysis by complement. There were both quantitative and qualitative 
differences between the $\mathrm{K}$ antigens of various $E$. coli strains and these differences correlated with bacterial resistance to serum.

Our results show that $E$. coli ML308 225 was most sensitive to the bactericidal action of serum when in the early-exponential phase of the growth cycle. Similar observations have been made with other strains of $E$. coli (Rowley \& Wardlaw, 1958; Davis \& Wedgwood, 1965). This phenomenon is particularly interesting in view of the decline in L.PS content during batch culture. Such a decline would be expected to promote greater serum sensitivity and we may conclude that there are other factors involved in the complement resistance of bacteria from the late-exponential and stationary phases of growth. Such factors may include the organization of the outer membrane and it may be significant that bacteria from the late-exponential phase of growth did not bind LPS. The relative proportions of the outer membrane proteins of $E$. coli B change during the course of a batch culture (Schnaitman, 1974) but these changes are less pronounced in E. coli ML308 225 (Allen \& Scott, 1979). It is unlikely that such changes make a significant contribution to the decline in serum sensitivity as a wide range of outer membrane protein-deficient mutants are approximately equally sensitive to serum (R. J. Allen \& G. K. Scott, unpublished results).

The binding of isolated LPS to bacteria and their subsequent protection from complement action confirms the importance of LPS levels in bacterial resistance to complement. In addition, if demonstrated for other bacterial strains, this phenomenon may also be of importance in the immunobiology of bacterial infection, since LPS released during bacterial growth, or as a result of localized complement action, could protect other organisms from complement.

We are grateful to Ms C. Thoreau for technical assistance and to Miss B. C. Saull, who typed the manuscript. The Medical Research Council of New Zealand provided financial support.

\section{REFERENCES}

ACKMAN, R. G. (1969). Gas-liquid chromatography of fatty acids and esters. Methods in Enzymology 14, 329-381.

Allen, R. J. \& ScotT, G. K. (1979). Biosynthesis and turnover of outer membrane proteins in Escherichia coli ML308 225. Biochemical Journal 182, 407-412.

Ames, G. F-L., Spudich, E. N.\& Nikaido, H. (1974). Protein composition of the outer membrane of Salmonella typhimurium: effect of lipopolysaccharide mutations. Journal of Bacteriology 117 , 406-416.

Archer, J. R. \& Rowley, D. (1969). Quantitative comparison of the antigenic structure of a virulent and an avirulent strain of Salmonella typhimurium. Inmunology 17, 551-558.

Davis, S. D. \& Wedgwood, R. J. (1965). Kinetics of the bactericidal action of normal serum on Gramnegative bacteria. Journal of Immunology 95, $75-79$.

Davis, S. D., Gemsi, D. \& Wedgwood, R. J. (1966). Kinetics of the transformation of Gramnegative rods to spheroplasts and ghosts by serum. Journal of Immunology 96, 570-577.

Devor, A.W. (1950). Carbohydrate tests using sulfonated $\alpha$-napthhol. Journal of the American Chemical Society 72, 2008-2021.

Di Rienzo, J. M., Nakamura, K. \& Inouye, M. (1978). The outer membrane proteins of Gramnegative bacteria: biosynthesis, assembly and functions. Annual Review of Biochemistry 47, 481-532.

Feingold, D. S., Goldman, J. N. \& Kuritz, H. M. (1968). Locus of the action of serum and the role of lysozyme in the serum bactericidal reaction. Journal of Bacteriology 96, 2118-2126.

Glynn, A. A. \& Howard, C. J. (1970). The sensitivity to complement of strains of Escherichia coli related to their $\mathrm{K}$ antigens. Immunology 18 , 331-346.

GlynN, A. A. \& Milne, C. M. (1967). A kinetic study of the bacteriolytic and bactericidal action of human serum. Immunology 12, 639-653.

Keogh, E. V., North, E. A. \& Warburton, M. F. (1948). Adsorption of bacterial polysaccharides to erythrocytes. Nature, London 161, 687-688.

LEIVE, L. (1965). Release of lipolysaccharide by EDTA treatment of E. coli. Biochemical and Biophysical Research Communications 21, 290296.

Lüderitz, O., Westphal, O., Staub, A. M. \& NIKAIDO, H. (1971). Isolation and chemical and immunological characterisation of bacterial lipopolysaccharides. In Microbial Toxins, vol. IV, pp. 145--233. Edited by G. Weinbaum, S. Kadis \& S. L. Ajl. New York: Academic Press.

Marr, A. G. \& Ingraham, J. L. (1962). Effect of temperature on the composition of fatty acids in Escherichia coli. Journal of Bacteriology 84, 1260 1267. 
Morrison, D. C. \& KLINE, L. F. (1977). Activation of the classical and properdin pathways of complement by bacterial lipopolysaccharides. Journal of Immunology 118, 362-368.

Rothfield, L. \& Pearlman-Kothencz, M. (1969). Synthesis and assembly of bacterial membrane components. A lipopolysaccharide-phospholipidprotein complex excreted by living bacteria. Journal of Molecular Biology 44, 477-492.

RowLEY, D. (1954). The virulence of strains of Bacterium coli for mice. British Journal of Experimental Pathology 35, 528-538.

Rowley, D. \& WARDLAW, A. C. (1958). Lysis of Gram-negative bacteria by serum. Journal of General Microbiology 18, 529-533.

SchNaITMAN, C. A. (1974). Outer membrane proteins of Escherichia coli. IV. Differences in outer membrane proteins due to strain and culture differences. Journal of Bacteriology 118, 454-464. STOLFI, R. L. (1968). Immune lytic transformation: a state of irreversible damage as a result of the reaction of the eighth component in the guinea pig complement system. Journal of Immunology $100,46-54$.

WARDLAW, A. C. (1963). The complement-dependent bacteriolytic activity of normal human serum. Cell wall composition of sensitive and resistant strains. Canadian Journal of Microbiology 9, 41-52.

Westphal, O. \& JanN, K. (1965). Bacterial lipopolysaccharides. Methods in Carbohydrate Chemistry 5, 83-91.

Wilson, B. M. \& GlynN, A. A. (1975). Release of ${ }^{14} \mathrm{C}$ label and complement killing of Escherichia coli. Immunology 28, 391-400. 